\title{
Why Must Forcible Action be the Only Way?: A New Approach for Initiating Quality Value of Voluntarily-Forcible Action (VF Action) in Stolen Asset Recovery
}

\author{
Ronald Hasudungan Sianturi
}

Faculty of Law, Universitas Prima Indonesia, Indonesia

\author{
P.L. Rika Fatimah \\ Faculty of Economics and Business, Universitas Gadjah Mada, Indonesia \\ Email: emailpaper@yahoo.com
}

Tan Kamello

Faculty of Law, Universitas Sumatera Utara, Indonesia

Doi:10.5901/jesr.2014.v4n6p429

\begin{abstract}
Recovering the proceeds of corruption is generally managed through forcible actions and leaving behind voluntary efforts. The preference for these forcible efforts can be seen from various international treaties regulating the seizure of the proceeds of crime. In reality, international treaties prioritizing forcible acts stumble upon many barriers especially in facing the difference in legal systems between the victim countries and recipient countries. On national level, forcible efforts also experience difficulties when perpetrators, stashing their stolen assets, are competing with law enforcement officials tracing and seizing their proceeds of corruption. This article provides a notion of the importance of combined voluntary and forcible actions to spend less efforts, time, and expenses during asset recovery process. This article using quality value approach on FuzzyServe and benchmarking to implement Voluntarily-Forcible Action (VF Action) in Stolen Asset Recovery.
\end{abstract}

Keywords: Benchmarking, corruption, forcible and voluntary action, fuzzyserve, Indonesia

\section{Introduction}

Corruption is a white-collar crime inflicting larger negative impacts than any other street crimes (Sutherland, 1939). Similar to other white-collar crimes, corruption can be identified by several characteristics, i.e. (1) perpetrator has respectable position in society, (2) perpetrator of criminal action should involve the use of (economical, political, or social) power for economical, social, or political purposes, and (3) victims of corruption are individuals and society (Stuart and McGurrin, 2013), making corruption a bigger threat compared to street crimes.

\subsection{Never-Endless of Indonesia's Battle for Corruption}

History recorded that Indonesia has been striving in combating corruption through the establishment of numerous institutions, such as Military Operation (Operasi Militer) in 1957, Corruption Eradication Team (Tim Pemberantasan Korupsi) in 1967, Clean Operation (Operasi Tertib) in 1977, and State Revenue from Taxation Optimization Team (Tim Optimalisasi Penerimaan Negara dari Sektor Pajak) in 1987. The excitement of combating against corruption acts has been increasing since the reform era with the establishment of a number of legal instruments including People's Consultative Assembly Decree (TAP MPR) No. XI/MPR/1998 on a Clean State Implementation Free from Corruption, Collusion, and Nepotism, Law No. 28 of 1999 on a Clean State Implementation Free from Corruption, Collusion, and Nepotism, Law No. 31 of 1999 on the Eradication of Criminal Acts of Corruption as amended by Law No. 20 of 2001, Joint Team for the Eradication of Corruption Acts (TKPTPK) in 1999, Corruption Eradication Commission (KPK) in 2003, and Corruption Acts Eradication Team (Timtas Tipikor) in 2005. Not to mention that the Government has also established Presidential instructions and mandates as well as anticorruption institutions such as the Financial Transaction Reporting and Analysis Center (PPATK) and Witness and Victim Protection Agency (LPSK). 


\subsection{The Dilemma of Fighting for Corruption or Stolen Asset Recovery}

At present, like other forms of white-collar crime, corruption is evolving, too (Agbiboa, 2012), along with the efforts of hiding the stolen assets. Forcible actions to seize the proceeds of corruption are performed by the Police, Prosecutor, and Corruption Eradication Commission (KPK). KPK admits to have been saving State's wealth at a valuation of Rp $121,655,680,319$ in 2012 (KPK, 2012). The number was a decrease from the previous year's achievement of Rp $138,062,072,084.30$ (KPK, 2011). Assets secured by KPK are smaller in number compared to assets saved by the Prosecutor which, in 2012, has secured Rp 292,930,351,734 and US\$ 500,000 from criminal proceedings. In addition to the number, the Prosecutor has also secured and recovered State's wealth through civil and state administrative proceedings amounting at Rp 2,459,267,500,792.83 and US\$ 46,249,463.32 and a land of 120,554 $\mathrm{m}^{2}$. The Prosecutor, further, has also established a Special Task Force for the Settlement of Seized and Execution Confiscation Goods responsible for recovering State's stolen assets. State assets secured in 2011 reached Rp 151,112,479,533 and significantly increased in 2012 to Rp 1,267,417,327,010 (RI Attorney General, 2012). According to Pratikno (2013), explicit expenses of corruption in 2012 have reached Rp 168.19 trillion, while only Rp 15.09 trillion or $8.97 \%$ were recovered to the State.

The failure in recovering the stolen assets through forcible actions was followed by Indonesian legal system's failure in protecting the perpetrators of corruption who have voluntarily surrendered the stolen assets. Agus Condro, having voluntarily surrendered the proceeds of corruption and become a justice collaborator, was charged with slightly different sentence from other perpetrators of the same case who did not hand over any of the stolen assets. The Jakarta Anticorruption Court Verdict No. 14/PID.B/TPK/2011/PN.JKT.PST declared, one aspect to commute Agus Condro's sentence was the fact that he has surrendered the stolen assets; his sentence, however, ended up with mere difference from other perpetrators' (see Table 1.). The followings are comparison of sentences imposed based on Verdict No. 14/PID.B/TPK/2011/PN.JKT.PST.

Table 1. Comparison of Sentences of Verdict No. 14/PID.B/TPK/2011/PN.JKT.PST

\begin{tabular}{|l|c|c|c|}
\hline \multicolumn{1}{|c|}{ Convict } & $\begin{array}{c}\text { Stolen Asset Voluntarily } \\
\text { Surrendered (in millions Rupiah) }\end{array}$ & Imprisonment & $\begin{array}{c}\text { Fine of subsidiary imprisonment of } \\
\text { 3 months (in millions Rupiah) }\end{array}$ \\
\hline Agus Condro Prayitno & 100 \& Apartment & 1 year 3 months & 50 \\
\hline Max Moein & None & 1 year 8 months & 50 \\
\hline Rusman Lumban Toruan & None & 1 year 8 months & 50 \\
\hline Williem Max Tutuarima & None & 1 year 6 months & 50 \\
\hline
\end{tabular}

The failure to recover stolen assets through forcible (confiscation) and voluntary actions needs immediate solution to avoid larger losses to the State resulted from the asset recovery expenses. Therefore, this study will discuss a quality value approach in combining the forcible and voluntary actions for stolen asset recovery. Voluntary efforts need to be developed to spend less efforts, time, and expenses during asset recovery process.

\section{The Importance of Punishment And Stolen Asset Recovery}

The utility of punishment comprises three theories, i.e. (1) retributive theory that considers punishment are given only as a response to crime; (2) utility theory that considers punishment are given not only as a response to crime, but also containing specific, beneficial purposes; and (3) combined theory that considers punishment has recovery effects on damages in the society. With Pancasila as the State's basic philosophy, the utility of punishment in Indonesia must consider the balance between individuals and community. A punishment grounded by the philosophy of Pancasila highlights the protection to victims, offenders, and community to recover the balance damaged by criminal acts.

The imposition of punishment for the protection of victims, offenders, and community is in conformity with the combined theory highlighting the recovery of damages once inflicted by corruption. This, however, is not implemented in Indonesian Anticorruption Law which emphasizes on imprisonment to perpetrators of corruption, accompanied with the imposition of fine as an effort to recover the stolen assets. Law No. 13 of 2006 on Protection for Witnesses and Victims merely gives protection to witnesses and victims of the criminal acts and cannot guarantee the security of perpetrators who are voluntarily willing to surrender the proceeds of corruption. This practice is a failed implementation of the combined theory of punishment. Lack of protection triggers arrested white-collar criminals to conceal their stolen assets instead of surrendering them voluntarily. The ingenuity of the perpetrators in hiding their stolen assets requires hard work 
from the State apparatus in recovering the proceeds of corruption. Dealing with these white-collar criminals will definitely deplete State's resources in terms of efforts, time, and expenses.

The State's failure in implementing the combined theory can be traced back to various cases which - regardless offenders' sentence to hand over the assets - still failed to recover the stolen assets. In reality, asset recovery through forcible actions is extremely hard to achieve as assets derived from corruption acts are very hard to trace. Therefore, making investigators managed to confiscate merely a little part of the assets, with much smaller value than the actual financial losses for cases or even no assets were found or confiscated (Table 2).

Table 2. The State's Failure to Recover the Stolen Asset within Various Cases

\begin{tabular}{|l|l|l|}
\hline \multicolumn{1}{|c|}{ White-Collar Criminal/Offenders } & \multicolumn{1}{|c|}{ Cases } & \multicolumn{1}{c|}{ Status of the Stolen Asset Recovery } \\
\hline Sudjiono Timan & $\begin{array}{l}\text { Bank Indonesia Liquidity } \\
\text { Assistance (BLBI) - Bahana } \\
\text { Pembinaan Usaha Indonesia }\end{array}$ & No assets were found/confiscated \\
\hline Sudjiono Timan & $\begin{array}{l}\text { Bank Indonesia Liquidity } \\
\text { Assistance (BLBI) - Bahana } \\
\text { Pembinaan Usaha Indonesia }\end{array}$ & $\begin{array}{l}\text { Smaller value than the actual financial losses were } \\
\text { confiscated. USD 98,000,000.00 and Rp. } \\
369.446 .905 .115,- \text { were not found. }\end{array}$ \\
\hline Samadikun Hartono & $\begin{array}{l}\text { Bank Indonesia Liquidity } \\
\text { Assistance (BLBI) - Modern Bank }\end{array}$ & $\begin{array}{l}\text { Smaller value than the actual financial losses were } \\
\text { confiscated. Rp. 169.472.986.461,54 were not found }\end{array}$ \\
\hline $\begin{array}{l}\text { Bambang Sutrisno and Adrian Kiki } \\
\text { Ariawan }\end{array}$ & $\begin{array}{l}\text { Bank Indonesia Liquidity } \\
\text { Assistance (BLBI) - Surya Bank }\end{array}$ & $\begin{array}{l}\text { Smaller value than the actual financial losses were } \\
\text { confiscated. Rp. 1.515.025.000.000,- were not found }\end{array}$ \\
\hline David Nusa Wijaya & $\begin{array}{l}\text { Bank Indonesia Liquidity } \\
\text { Assistance (BLBI) - Sertivia Bank }\end{array}$ & $\begin{array}{l}\text { No assets were found/confiscated including Rp. } \\
1.291 .530 .307 .776,84\end{array}$ \\
\hline Hendra Rahardja, Eko Edi Putratonto & $\begin{array}{l}\text { Bank Indonesia liquidity } \\
\text { and Sherny Kojongian } \\
\text { Sentance (BLBI) - Harapan }\end{array}$ & $\begin{array}{l}\text { Only Rp. 729.493.888.865,24,-- from Rp. } \\
1.950 .995 .354 .200,- \text { were confiscated }\end{array}$ \\
\hline Adrian Waworuntu & BNI Kabayoran Baru Branch & Smaller value than the actual financial losses \\
\hline I Wayan Pugeg & $\begin{array}{l}\text { The Indonesian Bureau of } \\
\text { Logistics }\end{array}$ & Smaller value than the actual financial losses \\
\hline H. Maulany Ghany Aziz & $\begin{array}{l}\text { The Indonesian Bureau of } \\
\text { Logistics }\end{array}$ & No assets were found/confiscated \\
\hline
\end{tabular}

Source: Let Out of Bargain, Settlement in Foreign Bribery Cases and Implications for Assets Recovery, The World Bank data, 2014: p. 76-78

\section{Initiating Quality Value on Voluntarily-Forcible Action for Stolen Asset Recovery}

Value on quality can be brought as a sincere approach to promote Voluntarily-Forcible Action (VF Action). Different with the forcible action that already in well structured in the implementation, voluntarily action is need for further exploration to be implemented. Vagueness and surely far from well structured lead the voluntarily action is a challenge to be implemented.

Therefore, bringing a sincere approach to get shorten gap between the offenders and the investigators is the main objective to get closer or even fully recover the stolen asset through a much lesser time, sources and cost to be spent. Deploying quality value is one of the ways to bring the sincere approach to win back the stolen assets. Two initiating approach on quality value for both voluntarily and forcible action shall bring about a new perspective to be further explored.

The approach will discuss into the following sub topic of initiating quality value of voluntarily motives and international treaties. Furthermore, a comprehensive illustration approach of FuzzyServe for voluntarily action and the priority table to the forcible action shall bring about a clearer recommendation of the VF action. In addition, the implementation of the VF action shall be as one of effective and efficient approach to promote stolen asset recovery.

\subsection{Initiating Quality Value Approach on FuzzyServe and Voluntarily Motives: An Approach to the Voluntarily Action}

The utility of punishment by way of the combined theory is also implemented in stolen asset recovery. Punishment should prioritize the recovery of the proceeds of corruption instead of imprisonment. For this reason, an attempt to encourage offenders to voluntarily surrender the stolen assets to minimize spent efforts, time, and expenses is in dire need. 
Implementing voluntarily action shall bring more voluntarily surrender of the stolen assets. To achieve the action, initiating of value on quality shall promote the process of giving back the stolen assets without time consume and costly way. Therefore, to promote the voluntarily action can be approach by using FuzzyServ or Fuzzy for Service. FuzzyServ is a new hybrid measurement used to measure service quality by using linguistic-humanistic numeric measurement (Mohamamd Nasir \& Rika Fatimah, 2004). The measurement is a collaboration technique of SERVQUAL or Service Quality (Zeithaml et al., 1996) and Fuzzy Logic (Zadeh, 1965).

FuzzyServe consider the before and after performance. In FuzzyServe, the customer who consumes the service will be asking regarding their hope before they consume the service. In addition, the customer also will be asking about their feeling after they really consume the service. In traditional measurement SERVQUAL, they only measure with a rigid number while the object of measurement is customer who has different feelings and expectation, not a rigid number. Therefore, Fuzzy logic shall measure to what extend the value happened to the customer. Fuzzy logic measurement applied ranges in degree of truth value. The truth may range between completely true and completely false. Linguistic variables also used to express the value rather than numbers alone (Rika Fatimah \& Mohammad Nasir 2003).

Derived from the concept of FuzzyServe, a voluntarily action shall be applied. The emphasis of the offenders' condition of 'before' and 'after' committing corruption can be uplifting as one of the technique to encourage the offenders to surrender the stolen assets voluntarily (Figure 1). Furthermore, an offender who performs an act voluntarily is under the impacts from internal and external factors. Internal factors are derived from perpetrator's personal condition such as individual traits, educational background, past experience, wishes, or future expectations. The internal factors is a reflective factors to condition of offenders 'before' committing corruption. Jackie McGudden (2000) noted that expectations encourage a person to perform voluntary act. The expectation to receive commutation of sentence following voluntary surrender of the stolen assets is not accommodated in current laws and regulations in Indonesia - voluntary surrender of stolen assets does not avoid a perpetrator from getting punishment, but only commuting her/his case for the judge before declaring the verdict. This notion does not give certainty on the commutation of sentence for a perpetrator, even if s/he voluntarily surrenders the stolen assets.

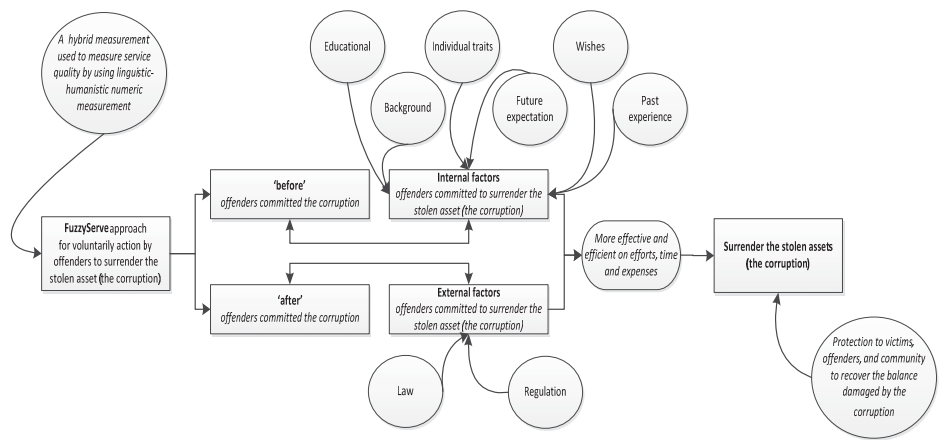

Figure 1. Initiating Quality Value for the Stolen Assets Recovery by using FuzzyServe Approach

Furthermore, external factors are also important in encouraging offenders to voluntarily surrender the proceeds of corruption. External factors, originated outside of the offender's self, among others include laws and regulations. The external factors are a reflective condition of offenders 'after' committing the corruption. Although currently not having special system to regulate voluntary recovery of stolen assets, Indonesia has encountered the practice of such action committed by Agus Condro for the case of Indonesian Bank (BI) Governor Bribery to the State through Corruption Eradication Commission (KPK). Andi Zulkarnain Mallarangeng for the case of Choel Mallarangeng has also surrendered US $\$ 550,000$ to KPK in relation to Hambalang Sports Center corruption case. Such examples show that the surrendering of the proceeds of corruption does not trigger any problem in terms of laws and regulations.

As result, an illustration on how initiating quality value to the voluntarily motives can bring a much more effective and efficient way by simplify the uses of sources to get back the stolen assets (Figure 1).

\subsection{Initiating Quality Value Approach on Benchmarking through the International Treaties: The Forcible Actions Priority}

Stolen asset recovery is in need of international treaties (Fofack, 2012), considering that the proceeds of corruption are 
hidden in foreign jurisdiction. International asset recovery highly prefers forcible measures in repatriating the proceeds of corruption. The United Nations Convention against Corruption (UNCAC) is a multilateral convention put together to combat corruption. The recovery of assets is established in Articles 51 to 59 regulating the General Provisions, Prevention, and Tracing of the proceeds of crime transfer, Actions to recover the assets directly, Mechanism to recover the stolen assets through international treaty in terms of asset seizure, International treaty for asset seizure, Special treaty, Asset return and sharing, Financial Intelligence Units, and Bilateral and multilateral treaties and regulations (Jack Smith, et al., 2007).

The regulation is fundamentally priority to establish the need for international cooperation in seizing proceeds of corruption hidden in recipient country and returning them to victim country. A strong built commitment between countries as international battle of corruptions shall bring also a strong forcible actions. Knowing that there will be no blind-spot to hide the stolen assets out of the offenders' country, shall force the offenders to more cooperate and choose the voluntarily action then surrenders the stolen assets to its state. Such international treaties prioritizing forcible measures in UNCAC 2003 stumble upon many barriers especially in facing difference in legal systems between the victim countries and recipient countries.

It is a challenge to adopt exactly legal systems upon countries due to the difference between the victim countries and recipient countries. Therefore, initiating quality value by using Benchmarking approach shall be consider as a strategic move to overcome the difference and emphasis the forcible action then to optimum to get back the stolen assets to victim countries. Benchmarking is the process of comparing best practices of quality, time and cost among different industries (Fifer, 1989). Even the difference in type of industries but each industry must have a similar process in detail. Therefore, apart of the differences, Benchmarking would prefer to look up carefully the similarities then consider its best practices to be applied to another industry that benchmarked. The objective is not on the result but on 'how' the other industries can success by having the best practice on its detail business operations.

In committing to mutual legal assistance with several countries, Indonesia also faces similar legal barriers with the Treaty between the Republic of Indonesia and Australia on Mutual Assistance in Criminal Matters; People's Republic of China on Mutual Legal Assistance in Criminal Matters; Republic of Korea on Mutual Assistance in Criminal Matters; Treaty on Mutual Legal Assistance in Criminal Matters (ASEAN MLA TREATY), and Agreement concerning Mutual Legal Assistance in Criminal Matters between Hong Kong and Indonesia. Therefore, having the Benchmarking approach, the countries stated above can be well reflected as industries. Each country that committing to mutual legal assistance can look up each best practice of quality, time and cost of handling the stolen assets from other countries. As result, a priority table that consist the best practice is as shown in Table 3 below;

Table 3. Proposed Priority Table to be Use for Initiating Quality Value by using Benchmarking Approach for Forcible Action Priorities among International Treaties

\begin{tabular}{|l|c|l|}
\hline Benchmarking per cases & $\begin{array}{c}\text { Best Practice } \\
\text { Countries }\end{array}$ & Forcible Action \\
\hline Alstom S.A & Switzerland & Payment of reparations $(\$ 1,089,510.00)$ \\
\hline BAE System plc & United Kingdom & Guilty Plea $(\$ 45,788,200.00)$ \\
\hline $\begin{array}{l}\text { Bayoil (USA), Inc. and Bayoil Supply \& Trading } \\
\text { Limited/David Chalmers }\end{array}$ & United States & Guilty plea $(\$ 9,016,151.00)$ \\
\hline Bribery of and by World Bank Offi cials/Gautam Sengupta & United States & Guilty plea $(\$ 127,000.00)$ \\
\hline $\begin{array}{l}\text { Bribery of Offi cials at Telecommunications } \\
\text { D'Haiti (Haiti Teleco)/Juan Diaz }\end{array}$ & United States & Guilty plea $(\$ 73,824.00)$ \\
\hline CBRN Ltd./Ananias Tumukunde & United Kingdom & Guilty plea $(\$ 73,242.00)$ \\
\hline Chevron Corporation (UN Oil-for-Food) & United States & Non-Prosecution Agreement $(\$ 20,000,000.00)$ \\
\hline El Paso Corporation & United States & Non-Prosecution Agreement $(\$ 5,482,363.00)$ \\
\hline El Paso Corporation/ Oscar J. Wyatt, Jr. & United States & Guilty Plea $(\$ 11,023,245.91)$ \\
\hline Julian Messent (PWS International Ltd.) & United Kingdom & Guilty plea $(\$ 157,399.00)$ \\
\hline $\begin{array}{l}\text { Kazakh Oil Mining/US Settlement (BOTA } \\
\text { Foundation) }\end{array}$ & United States & Memorandum of understanding $(\$ 84,000,000.00)$ \\
\hline Mabey \& Johnson Ltd & United Kingdom & Guilty plea $(\$ 2,296,021.00)$ \\
\hline Oxford University Press & United Kingdom & Civil recovery order $(\$ 3,135,220.00)$ \\
\hline Vitol SA (UN Oil-for-Food) & United States & Guilty plea $(\$ 13,000,000.00)$ \\
\hline Weir Group plc & United Kingdom & Guilty plea $(\$ 2,375,790.00)$ \\
\hline
\end{tabular}




\section{Conclusion}

The recovery of stolen assets should prioritize voluntary surrendering of assets while forcible acts should serve as a last resort when voluntary efforts fail. A factor in encouraging perpetrator of corruption to voluntarily surrender the stolen assets is the expectation of a commutation of sentence following the recovery of the assets. The certainty of a commutation of sentence for voluntary surrender of stolen asset should be regulated to encourage legal offenders to perform voluntary action in the recovery of the proceeds of corruption along with the forcible action.

Combining both action of voluntarily and forcible actions shall bring a more effective and efficient process to the stolen asset recovery. Deploying quality value is one of the ways to bring the sincere approach to win back the stolen assets. Two initiating approach on quality value for both voluntarily and forcible action are the concept of FuzzyServe and Benchmarking. Derived from the concept of FuzzyServe, a voluntarily action shall be applied with regard to the certainty of lesser punishment 'after' the surrender of the stolen asset. In addition, a 'before' factor to touch the sincere sense of humanity can be also applied to support the process of voluntarily action.

Furthermore, forcible action can be approach by international collaborator. A good cooperation between the victim and recipient countries shall force further the offenders to return the stolen asset. In addition, benchmarking among countries may create a dynamic process to define what are the priorities action shall be refer to from the best practice through the benchmarking approach. Having both voluntarily and forcible or namely VF Action shall bring a much more effective and efficient to achieve the stolen asset recovery.

\section{Acknowledgments}

This paper is presented in Workshop and Coaching on Writing Publication in International Journal (WCWPIJ) 2014, Malaysia. Therefore, the authors express their gratitude to ThinkSmart Scholar (TS Scholar) for the event and the support during the preparation of this article. Our sincere thank you to Assoc. Prof. Dr. Zinatul A. Zainol from Universiti Kebangsaan Malaysia for her inputs in the perfection of this article.

\section{References}

Agbiboa, Daniel Egiegba. (2013). Corruption and economic crime in Nigeria, social and economic perspective. African Security Perspective, 22(1), 47-66.

Corruption Eradication Commission. (2011). Annual Report, p. 54.

Corruption Eradication Commission. (2012). Annual Report, p. 56.

Fifer, R. M. (1989). Cost benchmarking functions in the value chain. Strategy \& Leadership, 17(3), 18-19.

Fofack, Hippolyte. (2012). Stolen Asset Recovery: The need for a global effort. Association of Concerned Africa Scholar Journal, 87, 2933.

Grehenson, Gusti, (2013), Uang Negara hilang Rp 250triliun akibat korupsi. [Online]. Available: http://ugm.ac.id/id/berita/8043uang.negara.hilang.rp.250.triliun.akibat.korupsi

Jack Smith, Pieth, Mark \& Guillermo. (2007). The Recovery of Stolen Assets: A Fundamental Principle of UN Convention Against Corruption. U4 Brief, Feb (2), 1-4.

Law. (2001). No. 20 on Amendment of Law No. 31 of 1999 on the Eradication of Criminal Acts of Corruption.

Law. (2006). No. 13 on Protection for Witnesses and Victims.

McCudden, Jackie. (2000). What makes a committees volunteer? Research into the factors affecting the retention of volunteers in Home-Smart. Voluntary Action, 2 (2), 59-75.

Mohamad Nasir Saludin \& Rika Fatimah P.L. (2004). External customer satisfaction and expectation approach on Regular Travel Package (RTP) in quality by design using fuzzy logic controller. Jurnal Sains Malaysiana, Bil. 33(1), 29-42. Universiti Kebangsaan Malaysia.

P.L., Rika Fatimah \& Mohamad Nasir Saludin. (2003). Fuzzy Logic Controller (FLC) application in the measurement system. Jurnal Matematika, Bil 1, 77-84. Universitas Islam Bandung Indonesia (UNISBA).

RI Attorney General Mandate. (2012). In the Commemoration of International Anticorruption Day. pp. 8-9.

Stuart, Henry \& McGurrin, Danielle. (2013). Preface. Western Criminology Review, 14(2), 1.

The World Bank. (2014). Let out of bargain, settlement in foreign bribery cases and implications for assets recovery. p. 76-78

Zadeh, L.A. (1965). Fuzzy sets. Information and Control, 8(3), 338-353.

Zeithaml,V. A., Berry, L. L. \& Parasuraman, A. (1996), The behavioural consequences of Service quality. Journal of Marketing, 60(April), 31-46. 